\title{
FELBERTALITE AND RELATED BISMUTH SULFOSALTS FROM THE FUNIUSHAN COPPER SKARN DEPOSIT, NANJING, CHINA
}

\author{
GU XIANG-PING ${ }^{\S}$, MAKOTO WATANABE, MAKIO OHKAWA, KENICHI HOSHINO \\ AND YASUHIRO SHIBATA
}

Department of Earth and Planetary Sciences, Hiroshima University, Hiroshima 739-8526, Japan

CHEN DESONG

Guilin Research Institute of Geology for Mineral Resources, Guangxi 541004, China

\begin{abstract}
Electron-microprobe and single-crystal X-ray-diffraction analyses have confirmed the second occurrence of felbertalite in the Funiushan copper skarn deposit, near Nanjing, in eastern China. It can be chemically described as $\mathrm{Cu}_{2} \mathrm{Ag}_{x} \mathrm{~Pb}_{6-2 x} \mathrm{Bi}_{8+x}(\mathrm{~S}, \mathrm{Se})_{19}$, with a wide range of substitution of $\mathrm{Bi}+\mathrm{Ag}$ for $2 \mathrm{~Pb}$, with $x$ ranging from 0.64 to 1.03 (probably up to 1.33 ), suggesting the presence of a solid-solution series in felbertalite. The measured unit-cell parameters of a felbertalite grain with a composition of $\mathrm{Cu}_{2.20} \mathrm{Ag}_{0.70} \mathrm{~Pb}_{4.65} \mathrm{Bi}_{8.45} \mathrm{~S}_{19.12}$ are: $a$ 27.68(4), $b$ 4.046(1), $c$ 20.67(3) $\AA, \beta$ 131.06(8) ${ }^{\circ}$, space group $C 2 / m$. A set of phases in the bismuthinite-aikinite series, mostly free of $\mathrm{Ag}$ and characterized by intermediate compositions between ideal formulae, were identified with electron-microprobe data. Compositional variations from $\mathrm{Cu}_{1.80} \mathrm{~Pb}_{1.80} \mathrm{Bi}_{2.20} \mathrm{~S}_{6}$, through $\mathrm{Cu}_{1.53} \mathrm{~Pb}_{1.53} \mathrm{Bi}_{2.47} \mathrm{~S}_{6}$, $\mathrm{Cu}_{1.07} \mathrm{~Pb}_{1.07} \mathrm{Bi}_{2.93} \mathrm{~S}_{6}, \mathrm{Cu}_{0.73} \mathrm{~Pb}_{0.73} \mathrm{Bi}_{3.27} \mathrm{~S}_{6}$, to $\mathrm{Cu}_{0.58} \mathrm{~Pb}_{0.58} \mathrm{Bi}_{3.42} \mathrm{~S}_{6}$ within a single grain were observed, indicating that an intergrowth of three structural units, i.e., bismuthinite ribbons, krupkaite ribbons and aikinite ribbons, could occur in the progressive exsolution or precipitation of a single phase in the bismuthinite-aikinite series. The exceptionally high contents of Ag $(0.76-1.27 \mathrm{wt} \%)$ in the phase $\mathrm{Cu}_{0.83} \mathrm{Ag}_{0.10} \mathrm{~Pb}_{0.90} \mathrm{Bi}_{3.13} \mathrm{~S}_{6}$, presumably corresponding to krupkaite, are noted. Electron-microprobe analyses have also revealed the occurrence of a number of rare minerals, including junoite, unknown $\mathrm{Cu}_{2} \mathrm{Ag}_{x} \mathrm{~Pb}_{10-2 x} \mathrm{Bi}_{12+x} \mathrm{~S}_{29}(1.23<x<1.49)$, berryite, benjaminite?, schirmerite?, Bi- and Ag-bearing galena, wittichenite and tetradymite. Within the intergrowths of $\mathrm{Cu}-\mathrm{Ag}-$ $\mathrm{Pb}-\mathrm{Bi}-\mathrm{S}(\mathrm{Se}, \mathrm{Te})$ minerals, $\mathrm{Te}$ (especially) and Se are preferably partitioned into Ag-bearing phases.
\end{abstract}

Keywords: felbertalite, bismuthinite-aikinite series, bismuth sulfosalts, unknown $\mathrm{Cu}_{2} \mathrm{Ag}_{x} \mathrm{~Pb}_{10-2 x} \mathrm{Bi}_{12+x} \mathrm{~S}_{29}$, copper skarn, Funiushan, Nanjing, China.

\section{SOMMAIRE}

Nous avons confirmé la présence de la felbertalite dans le gisement de skarn cuprifère de Funiushan, près de Nanjing, dans la partie orientale de la Chine, avec des analyses à la microsonde électronique et par diffraction X sur cristal unique. Il s'agit du deuxième exemple connu. Sa composition peut s'exprimer par la formule $\mathrm{Cu}_{2} \mathrm{Ag}_{x} \mathrm{~Pb}_{6-2 x} \mathrm{Bi}_{8+x}(\mathrm{~S}, \mathrm{Se})_{19}$; il y a un grand intervalle de substitution de $\mathrm{Bi}+\mathrm{Ag}$ pour $2 \mathrm{~Pb}$, avec $x$ entre 0.64 et 1.03 (et même probablement jusqu'à 1.33), ce qui indiquerait la présence d'une solution solide dans la felbertalite. Les paramètres réticulaires d'un grain ayant une composition de $\mathrm{Cu}_{2.20} \mathrm{Ag}_{0.70} \mathrm{~Pb}_{4.65} \mathrm{Bi}_{8.45}$ $\mathrm{S}_{19.12}$ sont: $a$ 27.68(4), $b 4.046(1), c 20.67(3) \AA ̊ ̊ 131.06(8)^{\circ}$, groupe spatial $C 2 / m$. Plusieurs phases de la série bismuthiniteaikinite, en général sans Ag et ayant une composition intermédiaire entre les formules idéales, ont été identifiées par microsonde électronique. Les variations en composition, de $\mathrm{Cu}_{1.80} \mathrm{~Pb}_{1.80} \mathrm{Bi}_{2.20} \mathrm{~S}_{6}$, en passant par $\mathrm{Cu}_{1.53} \mathrm{~Pb}_{1.53} \mathrm{Bi}_{2.47} \mathrm{~S}_{6}, \mathrm{Cu}_{1.07} \mathrm{~Pb}_{1.07} \mathrm{Bi}_{2.93} \mathrm{~S}_{6}$, $\mathrm{Cu}_{0.73} \mathrm{~Pb}_{0.73} \mathrm{Bi}_{3.27} \mathrm{~S}_{6}$, jusqu'à $\mathrm{Cu}_{0.58} \mathrm{~Pb}_{0.58} \mathrm{Bi}_{3.42} \mathrm{~S}_{6}$, ont été trouvées à l'intérieur d'un seul grain, indication qu'une intercroissance de trois unités structurales, c'est-à-dire, les rubans de bismuthinite, de krupkaïte et d'aikinite, a pu se former au cours de l'exsolution progressive ou de la précipitation d'une seule phase de la série bismuthinite-aikinite. Nous notons les teneurs anormalement élevées d' $\mathrm{Ag}\left(0.76-1.27 \%\right.$, par poids) dans la phase $\mathrm{Cu}_{0.83} \mathrm{Ag}_{0.10} \mathrm{~Pb}_{0.90} \mathrm{Bi}_{3.13} \mathrm{~S}_{6}$, que nous attribuons à la krupkaïte. Les analyses à la microsonde électronique révèlent aussi la présence de plusieurs minéraux rares, par exemple junoïte, $\mathrm{Cu}_{2} \mathrm{Ag}_{x}$ $\mathrm{Pb}_{10-2 x} \mathrm{Bi}_{12+x} \mathrm{~S}_{29}(1.23<x<1.49)$ méconnu, berryite, benjaminite?, schirmerite?, galène enrichie en Bi et Ag, wittichenite et tétradymite. Dans les intercroissances de minéraux de $\mathrm{Cu}-\mathrm{Ag}-\mathrm{Pb}-\mathrm{Bi}-\mathrm{S}(\mathrm{Se}, \mathrm{Te})$, le $\mathrm{Te}$, particulièrement, et le $\mathrm{Se}$ sont préférentiellement répartis dans les phases riches en $\mathrm{Ag}$.

(Traduit par la Rédaction)

Mots-clés: felbertalite, série de la bismuthinite-aikinite, sulfosels de bismuth, $\mathrm{Cu}_{2} \mathrm{Ag}_{x} \mathrm{~Pb}_{10-2 x} \mathrm{Bi}_{12+x} \mathrm{~S}_{29}$ méconnu, skarn cuprifère, Funiushan, Nanjing, Chine.

§ E-mail address: guxp@geol.sci.hiroshima-u.ac.jp 


\section{INTRODUCTION}

China is a country rich in bismuth resources, with total recoverable reserves about 481,400 tonnes of metallic bismuth in 1994 (Song 1998). Bismuth sulfosalt minerals are distributed in various types of deposits, including high-temperature hydrothermal $\mathrm{W}-\mathrm{Bi}$ quartz vein, skarn-type $\mathrm{Cu}, \mathrm{Pb}$ and $\mathrm{Zn}$ deposits, and mesothermal $\mathrm{Cu}, \mathrm{Pb}, \mathrm{Zn}$ and $\mathrm{Au}-\mathrm{Ag}$ deposits (Liang et al. 1981, Hong et al. 1982, Ren 1965, 1998). However, detailed mineralogical studies are still quite few, and not in keeping with the rich bismuth resources available for detailed investigation.

During a mineralogical investigations of the ores from the Funiushan copper skarn deposit, Nanjing, China, a suite of $\mathrm{Cu}-\mathrm{Ag}-\mathrm{Pb}-\mathrm{Bi}-\mathrm{S}-\mathrm{Se}-\mathrm{Te}$ minerals were identified by ore microscopy and electron-probe micro-analysis (EPMA). Among these, the presence of felbertalite was confirmed by single-crystal X-ray diffraction. New information on minerals in this assemblage was obtained, though most of the phases still need confirmation by X-ray diffraction. We report here the occurrences of these minerals with an emphasis on felbertalite and the bismuthinite-aikinite series.

\section{Geological Setting and Sample Description}

The Funiushan copper deposit, located about $26 \mathrm{~km}$ east of Nanjing City, Jiangsu Province in eastern China (Fig.1), is genetically related to the Funiushan granodiorite complex, which covers an area about $4.5 \mathrm{~km}^{2}$. The intrusive complex consists of porphyritic granodiorite, granodiorite porphyry, quartz dioritic porphyry and quartz syenite porphyry. According to Ye (1999), two stages of intrusion occurred in the Yanshanian Period, the earlier porphyritic granodiorite and granodiorite porphyry being followed by quartz diorite porphyry and quartz syenite porphyry. The $\mathrm{Rb}-\mathrm{Sr}$ isochron age of the granodiorite porphyry was reported to be $111 \pm 1 \mathrm{Ma}$ with an initial ${ }^{87} \mathrm{Sr} /{ }^{86} \mathrm{Sr}$ ratio of $0.7058 \pm 0001$ (Ye 1999).

Skarn rocks occur at the contact of the Yanshanian intrusive rocks and Upper Devonian quartz sandstone and slate hornfels. No apparent spatial relation is observed between the skarn and the Upper Devonian carbonate rocks.

The copper orebodies, striking NE or EW, occur in association with skarn or skarn hornfels and locally are hosted in the sandstone of the Wutong Group of the

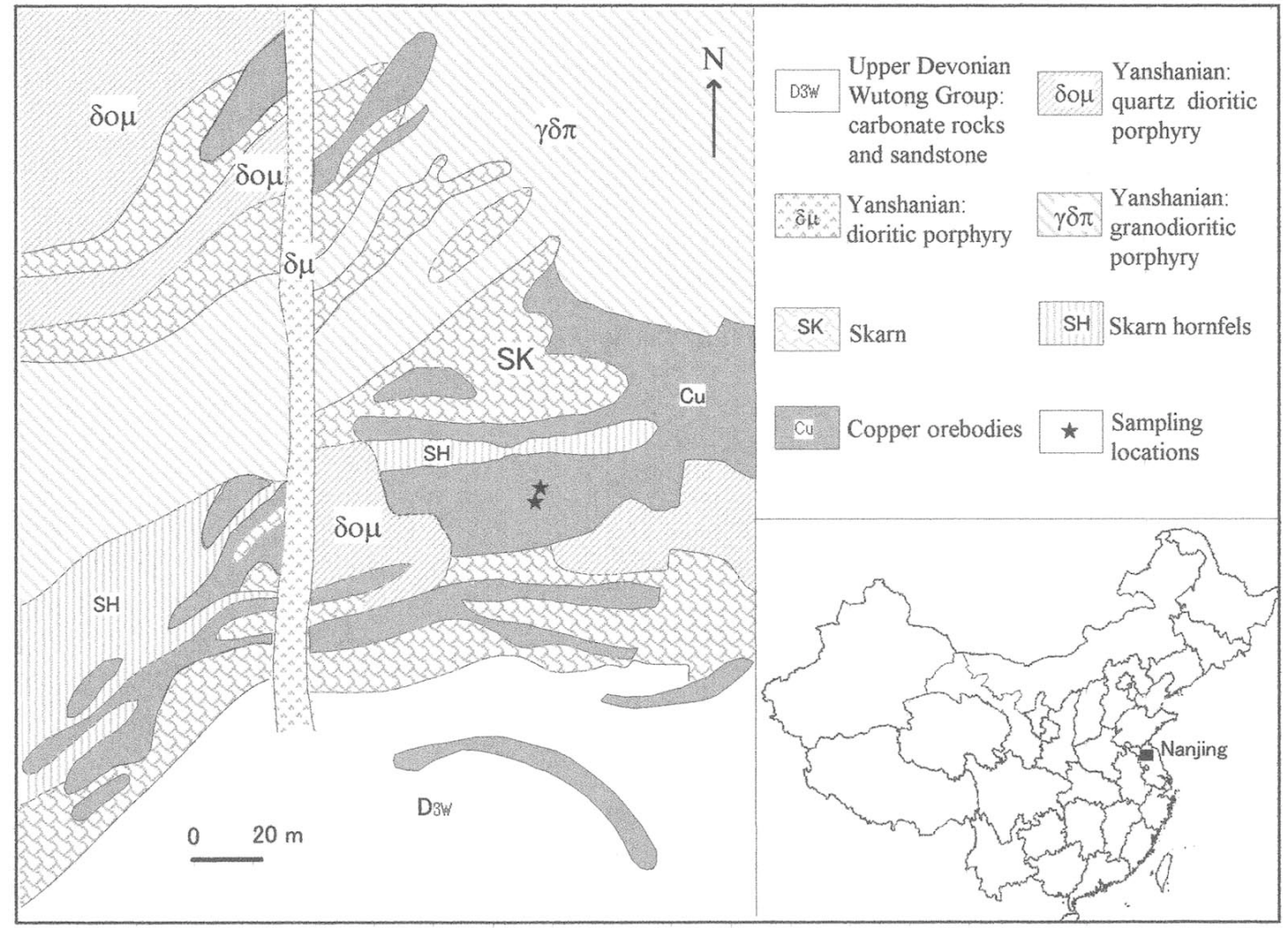

FIG. 1. Geological map and sampling locations on the $+60 \mathrm{~m}$ level of the Funiushan skarn copper deposit (after Zhang 1998). 
Upper Devonian System (Fig. 1). Total copper metal reserves of the deposit are estimated to be less than 100,000 tonnes, almost exhausted by now. Ore minerals are mainly pyrite and chalcopyrite, with minor amounts of pyrrhotite, siegenite, sphalerite and galena. Trace $\mathrm{Au}-\mathrm{Ag}$ alloy also is present in association with siegenite and chalcopyrite. The gangue minerals include mainly andraditic garnet, carbonate and quartz. The average grade of ores on the $+30 \mathrm{~m}$ and $+60 \mathrm{~m}$ levels is: $1.08 \% \mathrm{Cu}, 0.66 \% \mathrm{Zn}, 50$ ppm Pb, <100 ppm Bi , 60 ppm Co, 40 ppm Ni, 21 ppm Se, 3.5 ppm Te, 0.35 ppm $\mathrm{Au}$ and $11.5 \mathrm{ppm} \mathrm{Ag.}$

Three out of 60 samples, collected at every 5 to $10 \mathrm{~m}$ on the $+60 \mathrm{~m}$ level, were found to contain an abundance of bismuth sulfosalt minerals. The samples are mainly composed of chalcopyrite (20 vol.\%), pyrite (5 vol.\%) and minor sphalerite, galena and siegenite. Hematite is commonly observed to enclose and replace bismuth sulfosalt minerals. Gangue minerals are dominated by andradite (>70 vol.\%) in grains that are concentrically zoned, with small amounts of quartz. Bismuth sulfosalt minerals, easily recognizable in polished sections by their gray-white color, occur as acicular aggregates or irregular grains up to $5 \times 0.3 \mathrm{~mm}$ in size. They are usually disseminated in intergranular spaces among andradite grains or along chalcopyrite grains. Back-scattered electron (BSE) images (Figs. 2, 3) reveal intimate intergrowths of $\mathrm{Cu}-\mathrm{Ag}-\mathrm{Pb}-\mathrm{Bi}-\mathrm{S}-\mathrm{Se}-\mathrm{Te}$ minerals, indistinguishable under the microscope. Textural relationships indicate that bismuth sulfosalts formed later than andradite, pyrite and most of the chalcopyrite, sphalerite and siegenite.

\section{Analytical Methods}

Polished sections containing bismuth sulfosalt minerals were carefully examined under the microscope. Their chemical compositions were established with a JEOL JCMA-733II electron-microprobe analyzer. The operating conditions were as follows: accelerating voltage $25 \mathrm{kV}$, probe current $12-15 \mathrm{nA}$, and beam diameter $5 \mu \mathrm{m}$. The spectral lines of $\mathrm{S} K \alpha, \mathrm{Cu} K \alpha, \mathrm{Fe} K \alpha, \mathrm{Se} L \alpha$, $\operatorname{Ag} L \alpha, \operatorname{Pb} M \alpha, \operatorname{Bi} M \alpha, \operatorname{Sb} M \alpha$ and $\mathrm{Te} M \alpha$ were used. Synthetic pure materials of Te, $\mathrm{Bi}, \mathrm{Ag}, \mathrm{Se}, \mathrm{Sb}$ and synthetic $\mathrm{CuFeS}_{2}$ and $\mathrm{PbS}$ were used as standards. The results were corrected on-line (ZAF).

Under the microscope, most of the $\mathrm{Cu}-\mathrm{Ag}-\mathrm{Pb}-\mathrm{Bi}$ sulfosalts show similar features, i.e., gray-white to yellowish white color, weak to clear bireflectance and anistropism. They are closely intergrown and difficult to distinguish from each other. Therefore, great attention was paid to back-scattered electron (BSE) images in order to distinguish the various phases in their intimate intergrowths and to ensure the selection of homogeneous areas for analytical work.

One grain of felbertalite in the polished section, about $400 \times 200 \mu \mathrm{m}^{2}$ in size (Fig. 2a), was removed from its andradite host and broken into several smaller grains. A rectangular crystal, $50 \times 150 \times 190 \mu \mathrm{m}^{3}$ in dimension, was mounted on fine glass capillary with epoxy. The intensity data were collected on a RIGAKU AFC-7R four-circle diffractometer with graphitemonochromatized MoK $\alpha$ radiation $(60 \mathrm{kv}, 250 \mathrm{~mA})$. A total of 4196 reflections were observed. The cell dimensions were determined by a least-squares method using 25 reflections. Detailed structural data will be published elsewhere.

\section{RESULTS}

\section{Felbertalite}

Felbertalite, the bismuth sulfosalt most commonly encountered in the deposit, in domains $30 \mu \mathrm{m}$ to $1.5 \mathrm{~mm}$ in size, usually forms acicular or granular intergrowths with aikinite and friedrichite in an intergranular position among grains of andradite or along grains of chalcopyrite (Figs. 2a-f).

Results of electron-microprobe analyses on 19 grains of felbertalite associated with aikinite and friedrichite are presented in Table 1 . The results agree well with the formula $\mathrm{Cu}_{2} \mathrm{Ag}_{x} \mathrm{~Pb}_{6-2 x} \mathrm{Bi}_{8+x}(\mathrm{~S}, \mathrm{Se})_{19}$, with $x$ ranging from 0.64 to 1.03 , except for an excess of $0.18-0.49 \mathrm{Cu}$ per formula. Two additional grains, one associated with berryite and wittichenite (no. e14 and e09 in Table 1, Fig. 3a) and another with pekoite, benjaminite and tetradymite (no. c31 and e36 in Table 1, Fig. 3b), have even higher Ag content, with $x$ equal to 1.12 and 1.33 atoms per formula unit (apfu).

One grain with $x$ equal to 0.70 (Fig. 2a) was confirmed by single-crystal X-ray diffraction to have space group $C 2 / m$, a 27.68(4), b 4.046(1), c 20.67(3) $\AA$, $\beta$ $131.06(8)^{\circ}$, which is in good agreement with the findings of Topa et al. (2000) determined on holotype felbertalite (Topa et al. 2001).

Felbertalite was recently discovered from Felbertal, Austria (Topa et al. 2000, 2001, Grice \& Ferraris 2000). The structural formula is $\mathrm{Cu}_{2} \mathrm{~Pb}_{6} \mathrm{Bi}_{8} \mathrm{~S}_{19}$ composed of en échelon staggered fragments of $(100)_{\mathrm{PbS}}$ layers alternating with periodically sheared $(111)_{\mathrm{Pbs}}$ layers two octahedra thick (Topa et al. 2000). The compositional data from the type locality (E. Makovicky, pers. commun.) and Spain (Marcoux et al. 1996) show that felbertalite contains a small amount of silver as a result of the substitution $\mathrm{Ag}+\mathrm{Bi}=2 \mathrm{~Pb}$ in $(111)_{\mathrm{Pbs}}$ layers, yielding a general formula $\mathrm{Cu}_{2} \mathrm{Ag}_{x} \mathrm{~Pb}_{6-2 x} \mathrm{Bi}_{8+x}(\mathrm{~S}, \mathrm{Se})_{19}$, with $x$ ranging from 0 to 0.79 . Nevertheless, a wide range of solid-solution substitution has not been reported to date. As shown by the compositions of felbertalite from the Funiushan copper deposit, up to three-fourth of the $\mathrm{Pb}$ in (111) $\mathrm{PbS}$ layers may be replaced by $\mathrm{Ag}+\mathrm{Bi}$, with $x$ ranging from 0.64 to 1.33 .

We note that an excess of $\mathrm{Cu}(0.18-0.49$, average 0.28 apfu) occurs in the formula in samples of felbertalite from the Funiushan deposit. Excess $\mathrm{Cu}$ was also observed in some lillianite homologues (Cook 

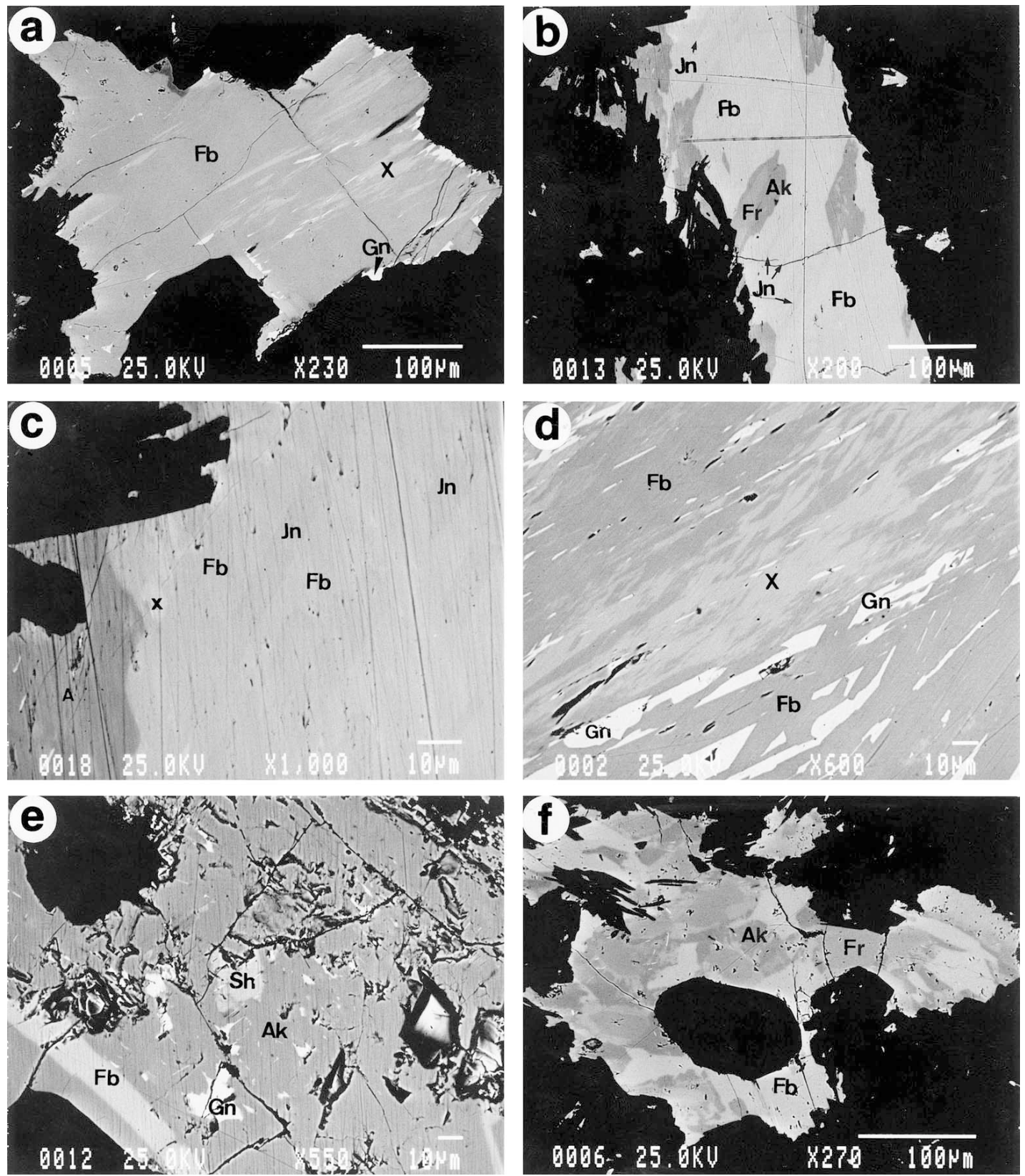

FIG. 2. Back-scattered electron images of bismuth sulfosalts. a. Felbertalite $(\mathrm{Fb})$ and exsolution patches of unknown $\mathrm{Cu}_{2} \mathrm{Ag}_{x}$ $\mathrm{Pb}_{10-2 x} \mathrm{Bi}_{12+x} \mathrm{~S}_{29}(\mathrm{X})$ and $\mathrm{Bi}$ - and Ag-bearing galena (Gn). b. Exsolution lamellae of junoite (Jn) in felbertalite (Fb) in association with aikinite (Ak) and friedrichite (Fr). c. Enlargement of part of b to show exsolution lamellae of junoite (Jn) in felbertalite $(\mathrm{Fb})$ in association with aikinite (Ak). d. Oriented exsolution-induced lamellae of unknown $\mathrm{Cu}_{2} \mathrm{Ag}_{\mathrm{x}} \mathrm{Pb}_{10-2 x} \mathrm{Bi}_{12+x} \mathrm{~S}_{29}$ $(\mathrm{X})$ and $\mathrm{Bi}$ - and $\mathrm{Ag}$-bearing galena $(\mathrm{Gn})$ in felbertalite $(\mathrm{Fb})$. e. Mineral association of aikinite (Ak), felbertalite $(\mathrm{Fb}), \mathrm{Bi}-\mathrm{and}$ Ag-bearing galena (Gn) and schirmerite? (Sh). f. Complex intergrowth of felbertalite (Fb), friedrichite (Fr) and aikinite (Ak). 
1997) and jaskolskiite and titinaite (Moëlo et al. 1995). In the experiments of Mariolacos (1979) and Sugaki et al. (1986), the " $\mathrm{AG}$ " phase $\mathrm{Cu}_{12} \mathrm{~Pb}_{25} \mathrm{Bi}_{38} \mathrm{~S}_{88}$ (or $\mathrm{Cu}_{2.56} \mathrm{~Pb}_{5.33} \mathrm{Bi}_{8.12} \mathrm{~S}_{18.77}$ based on $\left.\mathrm{Cu}+\mathrm{Pb}+\mathrm{Bi}=16\right)$, $\mathrm{a}$ possible synthetic equivalent of felbertalite, also showed excess $\mathrm{Cu}$ compared to $\mathrm{Cu}_{2} \mathrm{~Pb}_{6} \mathrm{Bi}_{8} \mathrm{~S}_{19}$, which is unlikely to be attributable to the substitution of $2 \mathrm{~Pb}$ by $\mathrm{Cu}+\mathrm{Bi}$. It seems that in the Funiushan samples, excess $\mathrm{Cu}$ may be involved in the substitutions of $\mathrm{Ag}+\mathrm{Cu}_{\text {interstitial }}$ for $\mathrm{Pb}, \mathrm{Cu}+\mathrm{Cu}_{\text {interstitial }}$ for $\mathrm{Pb}$ and, less probably, $\mathrm{Cu}+$ $2 \mathrm{Cu}_{\text {interstitial }}$ for $\mathrm{Bi}$.

\section{The bismuthinite-aikinite series}

Minerals in the bismuthinite-aikinite series, usually constituting complex solid-solution intergrowths from $20 \mu \mathrm{m}$ to more than $1 \mathrm{~mm}$ in size, are commonly seen in association with felbertalite (Figs. 2a-f), benjaminite and $\mathrm{Bi}$ - and Ag-bearing galena (Figs. 2e, 3b, 3d-f). Their compositions are plotted linearly on the bismuthinite-aikinite join characterized by $\mathrm{Cu}$ equal to $\mathrm{Pb}$, mostly located between the ideal compositions of indi- vidual minerals in this series (Fig. 4). According to the general formula $\mathrm{Cu}_{x} \mathrm{~Pb}_{x} \mathrm{Bi}_{4-x} \mathrm{~S}_{6}$ proposed by Žák (1980), the corresponding values of $x$ are calculated to be between 1.90 and 0.17 , as shown in Table 2 . In the range of $x$ from 1.90 to 1.53 , two distinct phases can be distinguished from textural evidence in BSE images (Figs. 2b, $\mathrm{f}, 3 \mathrm{c}$ ), one with $x$ from 1.90 to 1.76 corresponding to aikinite, another with $x$ from 1.74 to 1.53 corresponding to friedrichite. Similarly, two phases can be distinguished in the range of $x$ from 0.41 to 0.17 , one with $x$ from 0.41 to 0.31 corresponding to pekoite and another with $x$ from 0.28 to 0.17 probably corresponding to $\mathrm{Pb}(\mathrm{Cu})$-bearing bismuthinite (Fig. 3f). We note that compositional variations from $x=1.80$ to 0.58 are observed from the margin to the core of a single grain (Fig. 3c), in which five compositional phases were distinguished according to the BSE image, with $x$ respectively around $1.80,1.53,1.07,0.71-0.75$ (average 0.73 ) and 0.58 . The grains associated with pekoite or wittichenite (Figs. 3a, d), 30 to $200 \mu \mathrm{m}$ in diameter, have compositions with $x$ from 0.94 to 0.88 , presumably of krupkaite, which, in contrast to other Ag-free

TABLE 1. RESULTS OF ELECTRON-MICROPROBE ANALYSES AND SINGLE-CRYSTAL X-RAY DIFFRACTION OF FELBERTALITE FROM THE FUNIUSHAN COPPER SKARN DEPOSIT

\begin{tabular}{|c|c|c|c|c|c|c|c|c|c|c|c|c|c|c|c|c|c|c|}
\hline & \multicolumn{10}{|c|}{ Weight $\%$} & \multicolumn{7}{|c|}{ apf $u$ based on $\Sigma$ cations $=16$} & \multirow{2}{*}{$\begin{array}{c}\text { Asso- } \\
\text { ciated } \\
\text { minerals }\end{array}$} \\
\hline & $\mathrm{Bi}$ & $\mathrm{Sb}$ & $\mathrm{Ag}$ & $\mathrm{Cu}$ & $\mathrm{Fe}$ & $\mathrm{Pb}$ & $\mathrm{Se}$ & $\mathrm{Te}$ & $\mathbf{S}$ & Total & $\mathrm{Cu}$ & $\mathrm{Ag}$ & $\begin{array}{l}\mathrm{Bi}+ \\
\mathrm{Sb}\end{array}$ & $\begin{array}{c}\mathrm{Pb}^{+} \\
\mathrm{Fe}\end{array}$ & $\begin{array}{c}\mathrm{S}+\mathrm{Se} \\
+\mathrm{Te}\end{array}$ & $\begin{array}{l}\mathrm{Pb}+ \\
2 \mathrm{Ag}\end{array}$ & $\begin{array}{l}\mathrm{Bi}- \\
\mathrm{Ag}\end{array}$ & \\
\hline$d 36$ & 49.22 & 0 & 1.93 & 3.87 & 0 & 27.23 & 1.3 & 0.29 & 16.45 & 100.29 & 2.19 & 0.64 & 8.45 & 4.72 & 19.08 & 6.00 & 7.81 & frd-gn \\
\hline $\mathrm{d} 22$ & 49.56 & 0.04 & 1.95 & 3.97 & 0 & 25.45 & 1.3 & 0.29 & 16.32 & 98.88 & 2.27 & 0.66 & 8.62 & 4.46 & 19.15 & 5.78 & 7.96 & frd-gn \\
\hline fol & 49.54 & 0.03 & 2.03 & 3.83 & 0 & 26.25 & 1.44 & 0.44 & 16.36 & 99.92 & 2.18 & 0.68 & 8.57 & 4.57 & 19.2 & 5.93 & 7.89 & aik-x-gn \\
\hline $\mathrm{f} 10^{*}$ & 49.67 & 0.03 & 2.13 & 3.94 & 0 & 27.14 & 1.38 & 0.46 & 16.59 & 101.34 & 2.20 & 0.70 & 8.45 & 4.65 & 19.12 & 6.05 & 7.75 & aik-x-gn \\
\hline d 34 & 49.40 & 0 & 2.17 & 4.26 & 0.11 & 25.48 & 1.49 & 0.39 & 16.57 & 99.86 & 2.39 & 0.72 & 8.5 & 4.42 & 19.22 & 5.86 & 7.78 & aik-frd \\
\hline d56 & 50.02 & 0 & 2.21 & 3.92 & 0.03 & 24.18 & 1.49 & 0.39 & 16.49 & 98.73 & 2.25 & 0.75 & 8.75 & 4.27 & 19.54 & 5.77 & 8.00 & aik-frd-jnt-x \\
\hline fo5 & 50.67 & 0 & 2.28 & 4.05 & 0 & 25.84 & 1.65 & 0.43 & 16.37 & 101.29 & 2.26 & 0.75 & 8.58 & 4.41 & 18.93 & 5.91 & 7.83 & aik-x-gn \\
\hline d24 & 50.94 & 0.01 & 2.30 & 4.02 & 0.03 & 24.55 & 1.37 & 0.35 & 16.98 & 100.54 & 2.26 & 0.76 & 8.74 & 4.25 & 19.66 & 5.77 & 7.98 & frd \\
\hline e 54 & 49.50 & 0.01 & 2.29 & 3.99 & 0 & 25.65 & 1.35 & 0.41 & 16.33 & 99.51 & 2.26 & 0.76 & 8.52 & 4.45 & 19.05 & 5.97 & 7.76 & frd-jnt-x \\
\hline $\mathrm{d} 23$ & 50.95 & 0 & 2.30 & 3.99 & 0.01 & 23.89 & 1.3 & 0.4 & 16.44 & 99.26 & 2.26 & 0.77 & 8.80 & 4.16 & 19.21 & 5.70 & 8.03 & frd-gn \\
\hline $\mathrm{d} 40$ & 50.01 & 0.01 & 2.34 & 4.03 & 0.01 & 24.63 & 1.51 & 0.44 & 16.3 & 99.28 & 2.29 & 0.78 & 8.64 & 4.29 & 19.16 & 5.85 & 7.86 & frd-jnt \\
\hline $\mathrm{d} 37$ & 50.59 & 0.01 & 2.34 & 4 & 0.02 & 23.06 & 1.45 & 0.33 & 16.52 & 98.32 & 2.3 & 0.79 & 8.85 & 4.07 & 19.56 & 5.65 & 8.06 & aik-frd-jnt \\
\hline d25 & 51.11 & 0.03 & 2.69 & 3.93 & 0 & 23.89 & 1.46 & 0.40 & 16.46 & 99.97 & 2.21 & 0.89 & 8.77 & 4.13 & 19.16 & 5.91 & 7.88 & frd \\
\hline 108 & 51.68 & 0.01 & 2.85 & 4.07 & 0.02 & 23.47 & 1.44 & 0.42 & 16.84 & 100.79 & 2.27 & 0.94 & 8.78 & 4.02 & 19.37 & 5,90 & 7.84 & aik \\
\hline $\mathrm{f} 15$ & 51.76 & 0 & 2.97 & 4.21 & 0.77 & 23.20 & 1.49 & 0.51 & 16.4 & 101.31 & 2.27 & 0.94 & 8.95 & 4.07 & 18.29 & 5.95 & 8.01 & aik-frd \\
\hline $\mathrm{d} 54$ & 51.10 & 0 & 2.90 & 3.99 & 0.18 & 24.26 & 1.52 & 0.42 & 16.22 & 100.6 & 2.21 & 0.95 & 8.72 & 4.18 & 18.6 & 6.08 & 7.77 & aik-jnt-x \\
\hline $\mathrm{d} 43$ & 51.99 & 0.02 & 2.95 & 4.07 & 0 & 22.71 & 1.91 & 0.48 & 16.17 & 100.29 & 2.28 & 0.97 & 8.85 & 3.90 & 18.94 & 5.84 & 7.88 & aik \\
\hline fl 2 & 52.34 & 0 & 2.98 & 4.25 & 0.10 & 22.65 & 2.05 & 0.63 & 16.05 & 101.05 & 2.35 & 0.97 & 8.85 & 3.87 & 18.64 & 5.81 & 7.88 & aik-frd \\
\hline e56 & 52.00 & 0.02 & 3.11 & 4.13 & 0.04 & 21.33 & 1.94 & 0.55 & 16.27 & 99.37 & 2.33 & 1.03 & 8.95 & 3.70 & 19.22 & 5.76 & 7.92 & frd \\
\hline el4 & 53.22 & 0 & 3.43 & 4.49 & 0.25 & 19.28 & 2.98 & 0.62 & 15.58 & 99.86 & 2.49 & 1.12 & 9.12 & 3.35 & 18.59 & 5.59 & 8.00 & wtc-ber \\
\hline $\mathrm{e} 09$ & 52.78 & 0 & 3.66 & 4.27 & 0.55 & 19.13 & 2.88 & 0.64 & 15.73 & 99.64 & 2.36 & 1.19 & 9.04 & 3.41 & 18.67 & 5.79 & 7.85 & wtc-ber \\
\hline c31 & 55.73 & & 3.92 & 4.21 & & 17.71 & 2.47 & 0.65 & 16.31 & 100.99 & 2.33 & 1.28 & 9.38 & 3.01 & 19.17 & 5.57 & 8.10 & pek-bnj \\
\hline e36 & 55.48 & 0.04 & 4.04 & 4.22 & 0.01 & 16.98 & 2.45 & 0.57 & 16.19 & 99.98 & 2.35 & 1.33 & 9.42 & 2.91 & 19.14 & 5.57 & 8.09 & pek-bnj \\
\hline
\end{tabular}

Unit-cell data for felbertalite $\left[\mathrm{Cu}_{2.20} \mathrm{Ag}_{0.70} \mathrm{~Pb}_{4.65} \mathrm{Bi}_{8.45}(\mathrm{~S}, \mathrm{Se}, \mathrm{Te})_{19.12}\right]$ from the Funiushan deposit: space group $\mathrm{C} 2 / m, a 27.68, b 4.046, c 20.67 \AA$, $\beta 131.06^{\circ}$. Unit-cell data for felbertalite $\left[\mathrm{Cu}_{2} \mathrm{~Pb}_{6} \mathrm{Bi}_{8} \mathrm{~S}_{19}\right]$ from Felbertal, Austria (Topa et al. 2000): space group C2/m, a 27.64, $b 4.05, c 20.74 \AA$, $\beta 131.26^{\circ}$. * The grain confirmed by single-crystal X-ray diffraction. apfi: atoms per formula unit.

Blank space: no analysis made. Symbols: aik: aikinite, bnj: benjaminite, ber: berryite, frd: friedrichite, gn: galena, jnt: junoite, pek: pekoite, wtc: wittichenite, $x$ : unknown $\mathrm{Cu}_{2} \mathrm{Ag}_{x} \mathrm{~Pb}_{10-2 x} \mathrm{Bi}_{12+x} \mathrm{~S}_{29}$. 

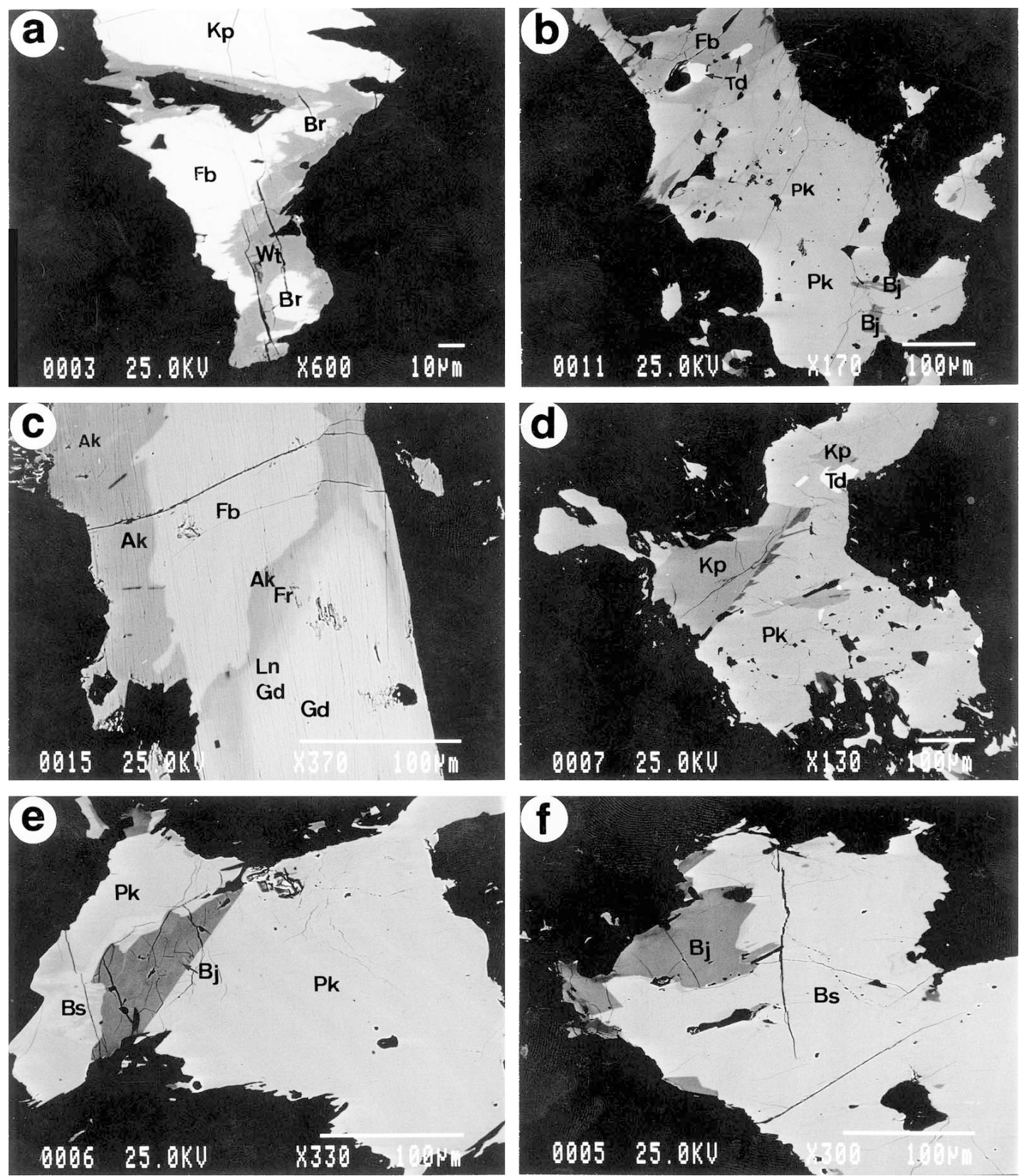

FIG. 3. Back-scattered electron images of bismuth sulfosalts. a. Mineral association of felbertalite $(\mathrm{Fb}, 1.12<x<1.19)$ and berryite $(\mathrm{Br})$ and krupkaite? $(\mathrm{Kp})$ surrounded by wittichenite ribbon $(\mathrm{Wt})$, with compositional zoning. b. Mineral association of pekoite $(\mathrm{Pk})$, felbertalite $(\mathrm{Fb}, 1.28<x<1.33)$, tetradymite $(\mathrm{Td})$ and benjaminite? $(\mathrm{Bj})$. c. Compositional zoning in a single grain from aikinite (Ak, $x=1.80)$, friedrichite ( $\mathrm{Fr}, x=1.53)$, lindstromite $(\mathrm{Ln}, x=1.07)$, gladite? $(\mathrm{Gd}, 0.75<x<0.58)$. Aikinite (Ak) shares common boundary with felbertalite $(\mathrm{Fb})$. d. Mineral association of krupkaite? (Kp), pekoite (Pk) and tetradymite (Td). e. Mineral association of benjaminite? $(\mathrm{Bj})$, pekoite $(\mathrm{Pk})$ and $\mathrm{Pb}$ - and $\mathrm{Cu}$-bearing bismuthinite $(\mathrm{Bs})$. $\mathrm{f}$. Mineral association of benjaminite? $(\mathrm{Bj})$ and $\mathrm{Pb}$ - and $\mathrm{Cu}$-bearing bismuthinite $(\mathrm{Bs})$. 


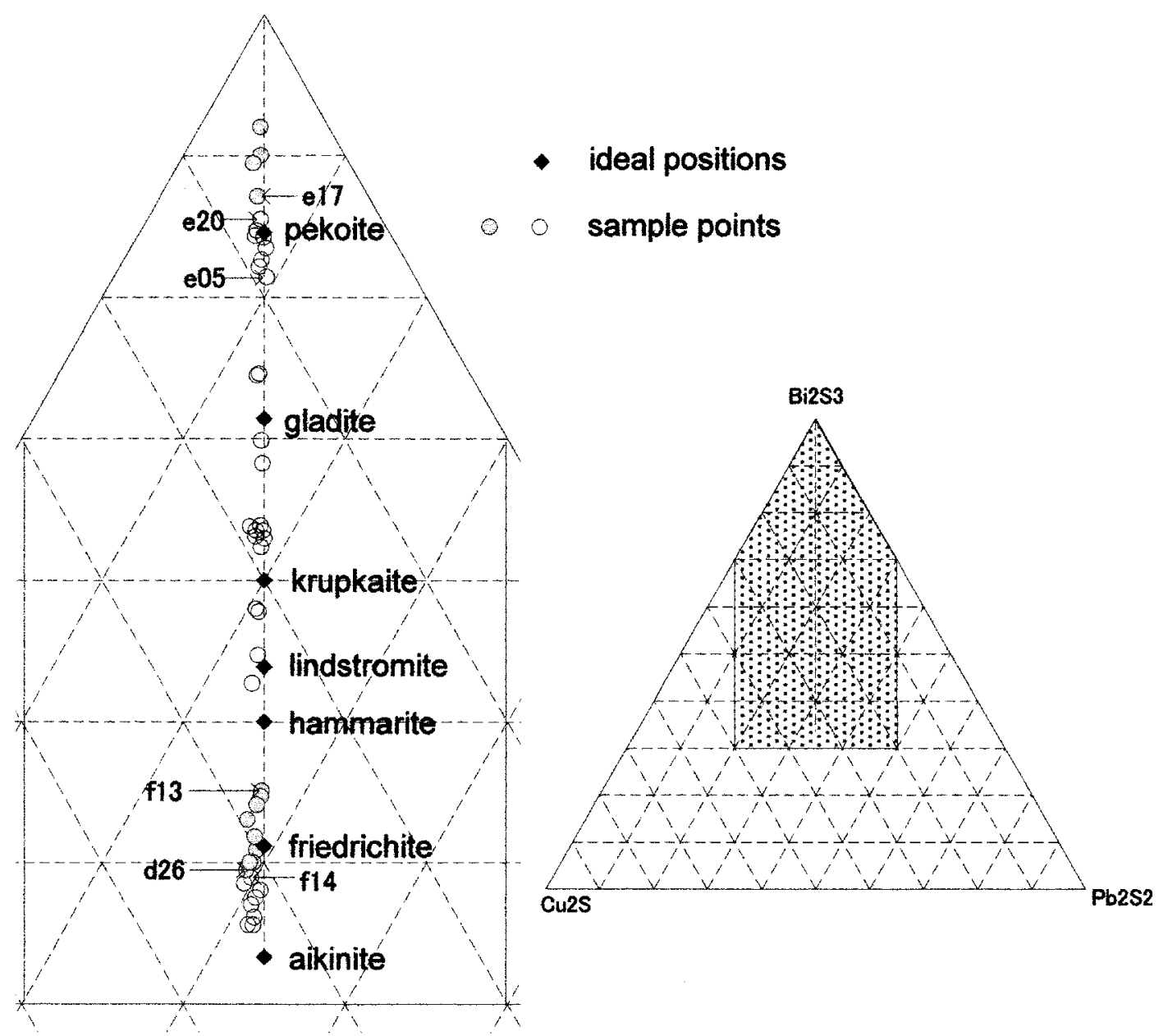

FIG. 4. The compositions of bismuthinite-aikinite series plotted in the system $\mathrm{Cu}_{2} \mathrm{~S}-\mathrm{Pb}_{2} \mathrm{~S}_{2}-\mathrm{Bi}_{2} \mathrm{~S}_{3}$.

phases in the bismuthinite-aikinite series, contains noticeable amounts of Ag (Table 2).

The compositions of members of the bismuthiniteaikinite series have been documented in numerous papers (e.g., Ciobanu \& Cook 2000, Cook 1997, Marcoux et al. 1996, Lowry et al. 1994, Mozgova et al. 1990, Large \& Mumme 1975). Most of the data are distributed in the range from aikinite to gladite, but the field between pekoite and bismuthinite is still poorly constrained. Structural refinements have shown that minerals of this series are composed of three basic structural units, i.e., the bismuthinite ribbon, the krupkaite ribbon and the aikinite ribbon (e.g., Harris \& Chen 1976, Kohatsu \& Wuensch 1976, Mumme \& Watts 1976). On the basis of the structural units, several methods were proposed to represent the crystal chemistry of the bismuthinite-aikinite series (e.g., Žák 1980, Makovicky \& Makovicky 1978, Mumme \& Watts 1976). Makovicky $\&$ Makovicky (1978) proposed the general formula $\mathrm{Cu}_{x} \mathrm{~Pb}_{y} \mathrm{Bi}_{8-(x+y) / 2} \mathrm{~S}_{12}$ in order to express the percentage of the krupkaite ribbons $\mathrm{n}_{\mathrm{k}}$ as [100-25(x+y)-100], which is calculated for the samples studied and shown in Table 2. Žák (1980) summarized the properties of 21 possible discrete phases in the bismuthinite-aikinite series and suggested the general formula $\mathrm{Cu}_{x} \mathrm{~Pb}_{x} \mathrm{Bi}_{4-x} \mathrm{~S}_{6}$, in which $x=(\mathrm{K}+2 \mathrm{~A}) / z$ or $0-2$ for ordered or disordered phases, where $\mathrm{K}$ and $\mathrm{A}$ are coefficients of krupkaite and aikinite ribbons, and $z$ is the multiple of $a_{0}$ of bismuthinite. High-resolution transmission electron microscopy (HRTEM) studies by Pring (1989, 1995) and Pring \& Hyde (1987) showed that the compositional variations in the bismuthinite-aikinite series are caused 
TABLE 2. RESULTS OF ELECTRON-MICROPROBE ANALYSES OF MINERALS OF THE BISMUTHINITE-AIKINITE SERIES FROM THE FUNIUSHAN COPPER SKARN DEPOSIT

\begin{tabular}{|c|c|c|c|c|c|c|c|c|c|c|c|c|c|}
\hline & \multirow[b]{2}{*}{ No. } & \multicolumn{10}{|c|}{ weight $\%$} & \multirow{2}{*}{$x^{*}$} & \multirow{2}{*}{$\begin{array}{c}n_{\mathrm{lrp}}{ }^{*} \\
\%\end{array}$} \\
\hline & & $\mathrm{Bi}$ & $\mathrm{Sb}$ & $\mathrm{Ag}$ & $\mathrm{Cu}$ & $\mathrm{Fe}$ & $\mathrm{Pb}$ & $\mathrm{Se}$ & $\mathrm{Te}$ & S & Total & & \\
\hline \multirow[t]{8}{*}{ aik } & $\mathrm{d} 31$ & 38.36 & 0.02 & 0.03 & 10.78 & 0.01 & 33.70 & 0.92 & 0.05 & 16.50 & 100.37 & 1.90 & 10.00 \\
\hline & f06 & 38.58 & 0 & 0 & 10.92 & 0 & 33.47 & 0.78 & 0.04 & 16.76 & 100.55 & 1.90 & 10.20 \\
\hline & $f 09$ & 39.26 & 0.02 & 0.01 & 10.76 & 0 & 33.75 & 0.69 & 0 & 17.31 & 101.80 & 1.88 & 12.35 \\
\hline & $\mathrm{d} 42$ & 39.62 & 0 & 0.01 & 10.53 & 0.03 & 32.60 & 0.68 & 0.02 & 16.45 & 99.94 & 1.84 & 16.00 \\
\hline & d39 & 40.80 & 0 & 0 & 10.53 & 0.02 & 33.12 & 0.70 & 0 & 16.67 & 101.83 & 1.82 & 18.20 \\
\hline & $\mathrm{d} 44^{\text {****}}$ & 41.00 & 0 & 0 & 10.24 & 0.02 & 32.83 & 0.57 & 0 & 16.71 & 101.37 & 1.80 & 20.47 \\
\hline & $\mathrm{d} 32$ & 40.94 & 0 & 0.07 & 10.32 & 0.04 & 31.13 & 0.75 & 0 & 17.08 & 100.34 & 1.78 & 22.30 \\
\hline & f14 & 41.69 & 0 & 0 & 10.20 & 0 & 31.52 & 0.61 & 0 & 16.95 & 100.95 & 1.76 & 24.29 \\
\hline \multirow[t]{9}{*}{ fdr } & d26 & 42.38 & 0.01 & 0.02 & 10.23 & 0 & 31.04 & 0.55 & 0.04 & 16.86 & 101.12 & 1.74 & 26.45 \\
\hline & d27 & 41.55 & 0 & 0 & 9.69 & 0.01 & 30.17 & 0.62 & 0 & 16.97 & 99.00 & 1.71 & 28.66 \\
\hline & e55 & 42.25 & 0 & 0 & 9.93 & 0.02 & 30.42 & 0.53 & 0 & 17.01 & 100.15 & 1.71 & 28.69 \\
\hline & d29 & 42.85 & 0.02 & 0.08 & 9.52 & 0 & 30.20 & 0.58 & 0.04 & 16.96 & 100.26 & 1.68 & 32.31 \\
\hline & d38 & 43.40 & 0 & 0 & 9.50 & 0.19 & 29.42 & 0.56 & 0.03 & 16.92 & 100.01 & 1.65 & 35.27 \\
\hline & d41 & 44.20 & 0 & 0.03 & 9.23 & 0.05 & 27.92 & 0.61 & 0 & 16.83 & 98.87 & 1.59 & 40.64 \\
\hline & d48 & 45.81 & 0 & 0 & 9.06 & 0.11 & 28.37 & 0.55 & 0 & 16.85 & 100.75 & 1.56 & 44.38 \\
\hline & $\mathrm{d} 45^{* *}$ & 46.47 & 0.03 & 0 & 8.85 & 0.04 & 28.36 & 0.64 & 0.02 & 16.87 & 101.29 & 1.53 & 46.91 \\
\hline & f13 & 46.47 & 0 & 0 & 8.87 & 0.31 & 28.01 & 0.56 & 0.01 & 17.03 & 101.25 & 1.53 & 47.47 \\
\hline \multirow[t]{4}{*}{ lnd? } & ffol 1 & 52.53 & & 0 & 7.40 & & 22.66 & 0.69 & 0.16 & 16.97 & & 1.24 & 74.50 \\
\hline & ffo 2 & 54.14 & & 0 & 6.94 & & 21.85 & 0.67 & 0.10 & 16.98 & 100.68 & 1.17 & 80.50 \\
\hline & d $46^{* *}$ & 55.70 & 0 & 0 & 6.30 & 0.01 & 19.87 & 0.91 & 0 & 17.21 & 100.00 & 1.07 & 92.85 \\
\hline & d $49^{* *}$ & 55.61 & 0.05 & 0 & 6.31 & 0.05 & 19.49 & 0.82 & 0.07 & 17.32 & 99.71 & 1.07 & 93.45 \\
\hline \multirow[t]{7}{*}{ krp? } & ell & 58.59 & 0 & 0.89 & 5.02 & 0.29 & 17.16 & 2.53 & 0.34 & 16.22 & 101.05 & 0.94 & 93.52 \\
\hline & e04 & 58.77 & 0.03 & 0.76 & 4.83 & 0.03 & 17.15 & 2.41 & 0.38 & 16.42 & 100.77 & 0.91 & 91.07 \\
\hline & e06 & 58.88 & 0 & 0.97 & 4.82 & 0.03 & 16.55 & 2.54 & 0.33 & 16.32 & 100.43 & 0.91 & 90.53 \\
\hline & $\mathrm{e} 03$ & 59.49 & 0 & 0.80 & 4.75 & 0 & 16.88 & 2.48 & 0.40 & 16.18 & 100.97 & 0.89 & 89.30 \\
\hline & e26 & 59.10 & 0.05 & 1.16 & 4.64 & 0.02 & 16.35 & 2.19 & 0.37 & 16.23 & 100.09 & 0.89 & 89.27 \\
\hline & e27 & 59.50 & 0 & 1.27 & 4.64 & 0 & 15.92 & 2.11 & 0.40 & 16.37 & 100.21 & 0.88 & 88.41 \\
\hline & $\mathrm{e} 01$ & 59.00 & 0.02 & 0.91 & 4.61 & 0 & 16.35 & 2.20 & 0.32 & 16.49 & 99.89 & 0.88 & 88.22 \\
\hline \multirow[t]{4}{*}{ gld? } & d52** & 63.11 & 0.04 & 0 & 4.50 & 0.02 & 14.42 & 0.84 & 0.01 & 17.40 & 100.34 & 0.75 & 75.42 \\
\hline & d51** & 64.30 & 0.05 & 0 & 4.28 & 0.01 & 13.58 & 0.97 & 0.01 & 17.45 & 100.64 & 0.71 & 70.97 \\
\hline & $\mathrm{d} 47^{* *}$ & 65.73 & 0.04 & 0.04 & 3.52 & 0.02 & 10.74 & 0.98 & 0.02 & 17.64 & 98.73 & 0.58 & 58.47 \\
\hline & d50** & 66.19 & 0.03 & 0 & 3.51 & 0.01 & 10.88 & 0.93 & 0 & 17.93 & 99.47 & 0.58 & 58.15 \\
\hline \multirow[t]{8}{*}{ pek } & e05 & 71.33 & 0 & 0 & 2.45 & 0.10 & 8.04 & 1.86 & 0 & 17.89 & 101 & 0.41 & 41.01 \\
\hline & el9 & 70.86 & 0.10 & 0.03 & 2.41 & 0 & 7.36 & 1.51 & 0.05 & 17.49 & 99.81 & 0.39 & 39.15 \\
\hline & e25 & 71.14 & 0.10 & 0 & 2.32 & 0.01 & 7.26 & 1.49 & 0 & 17.16 & 99.46 & 0.38 & 37.95 \\
\hline & e35 & 71.34 & 0.11 & 0 & 2.12 & 0.02 & 7.04 & 1.66 & 0.01 & 17.84 & 100.17 & 0.36 & 35.94 \\
\hline & e02 & 72.59 & 0 & 0 & 2.09 & 0.17 & 6.43 & 1.50 & 0 & 17.56 & 100.33 & 0.34 & 34.28 \\
\hline & e34 & 71.73 & 0.08 & 0.03 & 2.15 & 0 & 6.11 & 1.84 & 0.05 & 17.71 & 99.70 & 0.34 & 33.87 \\
\hline & c32 & 72.42 & & 0.15 & 2.01 & & 6.09 & 1.79 & 0.10 & 18.21 & 100.77 & 0.33 & 33.03 \\
\hline & $\mathrm{e} 20$ & 73.51 & 0.02 & 0 & 1.95 & 0.10 & 5.81 & 1.41 & 0 & 17.60 & 100.40 & 0.31 & 31.20 \\
\hline \multirow[t]{4}{*}{ bmt } & $\mathrm{e} 17$ & 74.05 & 0.13 & 0.03 & 1.76 & 0 & 5.09 & 1.68 & 0 & 17.54 & 100.27 & 0.28 & 27.50 \\
\hline & $\mathrm{e} 22$ & 76.51 & 0.10 & 0.15 & 1.46 & 0.07 & 3.77 & 1.25 & 0.06 & 17.91 & 101.27 & 0.22 & 22.22 \\
\hline & el6 & 76.18 & 0.21 & 0.02 & 1.33 & 0 & 4.00 & 1.53 & 0.06 & 17.57 & 100.91 & 0.21 & 20.93 \\
\hline & el5 & 76.47 & 0.16 & 0 & 1.07 & 0 & 3.09 & 1.53 & 0.11 & 17.09 & 99.51 & 0.17 & 16.53 \\
\hline
\end{tabular}

* $x$ : calculated values according to the general formula $\mathrm{Cu}_{x} \mathrm{~Pb}_{x} \mathrm{Bi}_{4-x} \mathrm{~S}_{6}$ (Zák 1980); $\mathbf{n}_{\mathrm{krp}}$; calculated percentages of the krupkaite ribbon, according to Makovicky \& Makovicky (1978).

** Analyses performed on the same grains, which show compositional zoning.

Blank space: no analysis was made. Symbols: aik: aikinite, bmt: bismuthinite, frd: friedrichite, gld: gladite, hmr: hammarite, krp: krupkaite, lnd: lindströmite, pek: pekoite

by ordered or disordered intergrowth of three structural units $(\mathrm{B}, \mathrm{K}$ and $\mathrm{A})$ related to cooling rate. Synthetic phases, as well as natural phases, reveal that Ag contents are very low in the bismuthinite-aikinite series (Chang et al. 1988).

In light of the above studies, the compositional variations of the bismuthinite-aikinite series from the
Funiushan deposit may be attributed to various intergrowths of three ordered structural ribbons. The compositional changes from $x=1.80$ to 0.58 within a single grain indicate that all three of the structural units may have been involved in the progressive exsolution or precipitation of a single phase. On the other hand, the exceptionally high Ag contents (0.76-1.27 wt.\%) of the 
phase with $x=0.94$ to 0.88 probably indicate a structural variant different from the three structural ribbons, for which an X-ray diffraction study is needed.

\section{Junoite}

Junoite was found to occur as oriented exsolutioninduced lamellae about $8 \mu \mathrm{m}$ in width in felbertalite (Figs. 2b, c). Two analyses showed that it is poor in $\mathrm{Ag}$ but richer in $\mathrm{Pb}$ than felbertalite (Table 3), suggesting a more limited substitution of $\mathrm{Ag}+\mathrm{Bi}$ for $2 \mathrm{~Pb}$. The formula is close to $\mathrm{Cu}_{2} \mathrm{~Pb}_{3} \mathrm{Bi}_{8} \mathrm{~S}_{16}$, comparable to those of Large \& Mumme (1975) and Pringle \& Thorpe (1980), except for minor excess $\mathrm{Cu}$. The presence of exsolution lamellae of junoite in a felbertalite host (Figs. 2b, c) indicates the similarity of their crystal structures, since both form part of the junoite-felbertalite homologous series, chemically characterized by $\mathrm{Cu}_{2} \mathrm{~Pb}_{3 \mathrm{~N}} \mathrm{Bi}_{8} \mathrm{~S}_{13+3 \mathrm{~N}}$ (Topa et al. 2000, Mumme 1980).
Unknown phase $C u_{2} A g_{x} P b_{10-2 x} B i_{12+x} S_{29}$

This phase occurs as oriented patches within felbertalite (Figs. 2a, d). Three electron-microprobe analyses gave an average formula $\mathrm{Cu}_{2.06} \mathrm{Ag}_{1.34} \mathrm{Bi}_{13.29}$ $\mathrm{Pb}_{7.34} \mathrm{~S}_{29.51}$ based on 24 cations (Table 3 ). It seems that $\mathrm{Cu}$ is essential and that $\mathrm{Ag}$ substitutes for $\mathrm{Pb}$ according to $\mathrm{Ag}+\mathrm{Bi}=2 \mathrm{~Pb}$, which yields a general formula $\mathrm{Cu}_{2} \mathrm{Ag}_{x} \mathrm{~Pb}_{10-2 x} \mathrm{Bi}_{12+x} \mathrm{~S}_{29}$, with $x$ ranging from 1.23 to 1.49. The Ag-free end member is $\mathrm{Cu}_{2} \mathrm{~Pb}_{10} \mathrm{Bi}_{12} \mathrm{~S}_{29}$.

\section{Berryite}

This phase occurs as irregular grains, 10 to $25 \mu \mathrm{m}$ in size, associated with felbertalite and Ag-bearing wittichenite (Fig. 3a). Chemically, it lies in the compositional range of berryite reported from other localities (Lowry et al. 1994, Cook 1997, Borodaev \& Mozgova

TABLE 3. RESULTS OF ELECTRON-MICROPROBE ANALYSES OF Cu-Ag-Pb-Bi-S(Se,Te) MINERALS ASSOCIATED WITH FELBERTALITE AND MINERALS OF THE BISMUTHINITE-AIKINITE SERIES IN THE FUNIUSHAN COPPER SKARN DEPOSIT

\begin{tabular}{|c|c|c|c|c|c|c|c|c|c|c|c|c|c|c|c|c|}
\hline & & \multicolumn{10}{|c|}{ weight $\%$} & \multicolumn{5}{|c|}{$a p f u^{*}$} \\
\hline & & $\mathrm{Bi}$ & $\mathrm{Sb}$ & $\mathrm{Ag}$ & $\mathrm{Cu}$ & $\mathrm{Fe}$ & $\mathrm{Pb}$ & $\mathrm{Se}$ & $\mathrm{Te}$ & S & Total & $\mathrm{Cu}$ & $\mathrm{Ag}$ & $\begin{array}{l}\mathrm{Bi+} \\
\mathrm{Sb}\end{array}$ & $\begin{array}{c}\mathrm{Pb}+ \\
\mathrm{Fe}\end{array}$ & $\begin{array}{c}\mathrm{S}+\mathrm{Se} \\
+\mathrm{Te}\end{array}$ \\
\hline junoite & $\begin{array}{l}\text { d55 } \\
\text { d57 }\end{array}$ & $\begin{array}{l}56.57 \\
55.53\end{array}$ & $\begin{array}{l}0.05 \\
0.01\end{array}$ & $\begin{array}{l}0.61 \\
1.14\end{array}$ & $\begin{array}{l}4.70 \\
4.59\end{array}$ & $\begin{array}{l}0.05 \\
0\end{array}$ & $\begin{array}{l}18.83 \\
19.34\end{array}$ & $\begin{array}{l}1.40 \\
1.32\end{array}$ & $\begin{array}{l}0.26 \\
0.21\end{array}$ & $\begin{array}{l}17.18 \\
17.14\end{array}$ & $\begin{array}{l}99.63 \\
99.27\end{array}$ & $\begin{array}{l}2.17 \\
2.13\end{array}$ & $\begin{array}{l}0.17 \\
0.31\end{array}$ & $\begin{array}{l}7.99 \\
7.82\end{array}$ & $\begin{array}{l}2.68 \\
2.75\end{array}$ & $\begin{array}{l}16.32 \\
16.26\end{array}$ \\
\hline $\begin{array}{l}\text { unknown } \\
\text { phase }\end{array}$ & $\begin{array}{l}\text { d53 } \\
\text { f02 } \\
\text { fl } 1\end{array}$ & $\begin{array}{l}48.66 \\
49.94 \\
50.23\end{array}$ & $\begin{array}{l}0 \\
0 \\
0.03\end{array}$ & $\begin{array}{l}2.86 \\
2.37 \\
2.56\end{array}$ & $\begin{array}{l}2.42 \\
2.38 \\
2.26\end{array}$ & $\begin{array}{l}0.19 \\
0 \\
0.02\end{array}$ & $\begin{array}{l}26.37 \\
27.11 \\
28.07\end{array}$ & $\begin{array}{l}2.12 \\
1.57 \\
1.67\end{array}$ & $\begin{array}{l}0.40 \\
0.53 \\
0.49\end{array}$ & $\begin{array}{l}15.90 \\
16.20 \\
16.34\end{array}$ & $\begin{array}{r}98.92 \\
100.09 \\
101.67\end{array}$ & $\begin{array}{l}2.13 \\
2.09 \\
1.96\end{array}$ & $\begin{array}{l}1.49 \\
1.23 \\
1.30\end{array}$ & $\begin{array}{l}13.05 \\
13.36 \\
13.27\end{array}$ & $\begin{array}{l}7.33 \\
7.32 \\
7.47\end{array}$ & $\begin{array}{l}29.48 \\
29.59 \\
29.45\end{array}$ \\
\hline berryite & $\begin{array}{l}\text { e12 } \\
\text { e29 } \\
\text { e30 }\end{array}$ & $\begin{array}{l}47.67 \\
46.19 \\
45.41\end{array}$ & $\begin{array}{l}0 \\
0 \\
0\end{array}$ & $\begin{array}{l}6.43 \\
6.95 \\
7.75\end{array}$ & $\begin{array}{l}7.27 \\
7.59 \\
7.74\end{array}$ & $\begin{array}{l}0.36 \\
0.35 \\
0.41\end{array}$ & $\begin{array}{l}19.96 \\
19.10 \\
19.50\end{array}$ & $\begin{array}{l}2.86 \\
2.86 \\
2.77\end{array}$ & $\begin{array}{l}0.05 \\
0.45 \\
0.94\end{array}$ & $\begin{array}{l}15.37 \\
15.63 \\
15.57\end{array}$ & $\begin{array}{r}99.95 \\
99.12 \\
100.09\end{array}$ & $\begin{array}{l}3.47 \\
3.59 \\
3.63\end{array}$ & $\begin{array}{l}1.81 \\
1.94 \\
2.14\end{array}$ & $\begin{array}{l}7.12 \\
6.84 \\
6.69\end{array}$ & $\begin{array}{l}2.93 \\
2.77 \\
2.80\end{array}$ & $\begin{array}{l}15.67 \\
15.86 \\
15.73\end{array}$ \\
\hline $\begin{array}{l}\text { benja- } \\
\text { minite? }\end{array}$ & $\begin{array}{l}\text { e18 } \\
\text { e23 } \\
\text { e24 } \\
\text { e28 } \\
\text { c33 } \\
\text { e32 } \\
\text { e33 }\end{array}$ & $\begin{array}{l}64.54 \\
65.02 \\
64.54 \\
63.26 \\
66.16 \\
64.77 \\
61.88\end{array}$ & $\begin{array}{l}0 \\
0 \\
0 \\
0 \\
\\
0 \\
0\end{array}$ & $\begin{array}{r}9.95 \\
9.13 \\
10.19 \\
10.64 \\
7.09 \\
8.41 \\
10.04\end{array}$ & $\begin{array}{l}3.14 \\
3.54 \\
3.33 \\
3.04 \\
3.36 \\
3.30 \\
3.26\end{array}$ & $\begin{array}{l}0.02 \\
0 \\
0.02 \\
0.04 \\
\\
0.02 \\
0.10\end{array}$ & $\begin{array}{l}3.69 \\
3.25 \\
2.20 \\
4.01 \\
4.45 \\
3.92 \\
4.80\end{array}$ & $\begin{array}{l}2.01 \\
2.55 \\
2.04 \\
3.02 \\
2.11 \\
2.10 \\
2.19\end{array}$ & $\begin{array}{l}0.46 \\
0.44 \\
0.30 \\
0.46 \\
0.20 \\
0.17 \\
0.18\end{array}$ & $\begin{array}{l}16.60 \\
16.61 \\
16.96 \\
16.02 \\
17.66 \\
17.21 \\
16.98\end{array}$ & $\begin{array}{r}100.40 \\
100.53 \\
99.58 \\
100.48 \\
101.04 \\
99.91 \\
99.42\end{array}$ & $\begin{array}{l}1.09 \\
1.21 \\
1.13 \\
1.06 \\
1.10 \\
1.10 \\
1.10\end{array}$ & $\begin{array}{l}2.03 \\
1.83 \\
2.03 \\
2.18 \\
1.36 \\
1.66 \\
2.00\end{array}$ & $\begin{array}{l}6.79 \\
6.74 \\
6.66 \\
6.73 \\
6.56 \\
6.60 \\
6.40\end{array}$ & $\begin{array}{l}0.39 \\
0.34 \\
0.23 \\
0.44 \\
0.44 \\
0.41 \\
0.52\end{array}$ & $\begin{array}{l}12.00 \\
12.00 \\
12.00 \\
12.00 \\
12.00 \\
12.00 \\
12.00\end{array}$ \\
\hline \multicolumn{2}{|c|}{ schirmerite?d30 } & 51.52 & 0.02 & 7.89 & 1.12 & 0.05 & 20.30 & 2.52 & 0.24 & 15.69 & 99.33 & 0.61 & 2.51 & 8.51 & 3.38 & 18.00 \\
\hline galena & $\begin{array}{l}\text { f04 } \\
\text { d33 } \\
\text { d35 }\end{array}$ & $\begin{array}{l}4.85 \\
4.96 \\
4.40\end{array}$ & $\begin{array}{l}0 \\
0.02 \\
0\end{array}$ & $\begin{array}{l}1.29 \\
1.59 \\
1.44\end{array}$ & $\begin{array}{l}0.10 \\
0.60 \\
0.40\end{array}$ & $\begin{array}{l}0.03 \\
0.02 \\
0\end{array}$ & $\begin{array}{l}82.20 \\
78.44 \\
80.77\end{array}$ & $\begin{array}{l}1.41 \\
3.16 \\
1.14\end{array}$ & $\begin{array}{l}0.16 \\
0.20 \\
0.09\end{array}$ & $\begin{array}{l}12.72 \\
11.91 \\
13.17\end{array}$ & $\begin{array}{l}102.77 \\
100.89 \\
101.41\end{array}$ & $\begin{array}{l}0.02 \\
0.02 \\
0.01\end{array}$ & $\begin{array}{l}0.03 \\
0.03 \\
0.02\end{array}$ & $\begin{array}{l}0.06 \\
0.05 \\
0.06\end{array}$ & $\begin{array}{l}0.89 \\
0.90 \\
0.91\end{array}$ & $\begin{array}{l}0.97 \\
0.99 \\
0.96\end{array}$ \\
\hline wittichenite & $\begin{array}{r}\mathrm{e} 07 \\
\mathrm{e} 08\end{array}$ & $\begin{array}{l}41.63 \\
40.89\end{array}$ & $\begin{array}{l}0 \\
0\end{array}$ & $\begin{array}{l}3.10 \\
1.59\end{array}$ & $\begin{array}{l}32.47 \\
35.12\end{array}$ & $\begin{array}{l}0.49 \\
0.51\end{array}$ & $\begin{array}{l}1.21 \\
2.01\end{array}$ & $\begin{array}{l}2.75 \\
1.47\end{array}$ & $\begin{array}{l}0.51 \\
0.24\end{array}$ & $\begin{array}{l}16.96 \\
17.98\end{array}$ & $\begin{array}{l}99.10 \\
99.81\end{array}$ & $\begin{array}{l}2.71 \\
2.83\end{array}$ & $\begin{array}{l}0.15 \\
0.08\end{array}$ & $\begin{array}{l}1.10 \\
1.00\end{array}$ & $\begin{array}{l}0.05 \\
0.09\end{array}$ & $\begin{array}{l}3.01 \\
2.97\end{array}$ \\
\hline tetradymite & $\mathrm{c} 30$ & 60.52 & & 0.11 & 0.08 & & 0 & 2.49 & 32.46 & 4.37 & 100.04 & & & & & \\
\hline
\end{tabular}

\footnotetext{
* Calculations based on a total of 13 cations for junoite, 24 cations for the unknown phase, 31 atoms for berryite, 12 anions atoms for benjaminite?, 18 anions for schirmerite?, 1 cation for galena, 4 cations for wittichenite, and 5 atoms for tetradymite. Blank space: no analysis was done. apfu: atoms per formula unit.
} 
1971, Nuffield \& Harris 1966). On the basis of 31 atoms in total, the results show an excess in $\mathrm{Cu}+\mathrm{Ag}$ and a deficiency in $\mathrm{Pb}$ with respect to $(\mathrm{Cu}, \mathrm{Ag})_{5} \mathrm{~Pb}_{3} \mathrm{Bi}_{7} \mathrm{~S}_{16}$. The chemical compositions of berryite are still poorly constrained. The type material was defined as $(\mathrm{Cu}, \mathrm{Ag})_{3}$ $\mathrm{Pb}_{2} \mathrm{Bi}_{5} \mathrm{~S}_{11}$, with a $\mathrm{Cu}: \mathrm{Ag}$ ratio between 1.4 and 2.4 (Nuffield \& Harris 1966), whereas accumulated data show it to be closer to $(\mathrm{Cu}, \mathrm{Ag})_{5} \mathrm{~Pb}_{3} \mathrm{Bi}_{7} \mathrm{~S}_{16}$ (Borodaev \& Mozgova 1971, Lowry et al. 1994, Cook 1997). The compositional data available invariably show the presence of appreciable amounts of both $\mathrm{Cu}$ and $\mathrm{Ag}$. No significant correlation seems to exist between $\mathrm{Cu}$ and $\mathrm{Ag}$. Neither Ag-free nor $\mathrm{Cu}$-free end members have been reported. Thus, the role of $\mathrm{Cu}$ and $\mathrm{Ag}$ in the structure still needs further study.

\section{Benjaminite?}

This phase occurs as irregular grains, $10-80 \mu \mathrm{m}$ in size, associated with pekoite and $\mathrm{Pb}(\mathrm{Cu})$-bearing bismuthinite (Figs. 3b, e, f). It contains constant $\mathrm{Cu}$ but variable $\mathrm{Bi}, \mathrm{Pb}$ and $\mathrm{Ag}$. No significant correlation was observed among these elements. The $(\mathrm{Bi}+\mathrm{Pb}) /(\mathrm{Cu}+$ $\mathrm{Ag}$ ) values vary between 3 and 2 . The compositions lie in the compositional ranges of benjaminite, pavonite and even makovickyite (Chang et al. 1988, Žák et al. 1994). We have ascribed it to benjaminite on the basis of the formula $\mathrm{Ag}_{3.43-(x+y)} \mathrm{Cu}_{y+(n+1) z} \mathrm{~Pb}_{2 x} \mathrm{Bi}_{6.85-(x+z)} \mathrm{S}_{12}$ proposed by Chang et al. (1988). Our calculations show that $z$ is near 0 and $\mathrm{Pb}$ may be involved in the substitutions of $\mathrm{Pb}=\mathrm{Ag}+\square$ and $\mathrm{Cu}_{\text {interstitial }}+\mathrm{Pb}=\mathrm{Bi}$ in addition to $2 \mathrm{~Pb}=\mathrm{Ag}+\mathrm{Bi}$. On the other hand, the constant levels of $\mathrm{Cu}$ may indicate that $\mathrm{Cu}$ occupies a unique position in the structure.

\section{Schirmerite?}

This phase was found to occur as a small grain about $12 \mu \mathrm{m}$ in diameter in aikinite (Fig. 2e). The electronmicroprobe results show it to lie in the compositional field of schirmerite $\left(\mathrm{Ag}_{3} \mathrm{~Pb}_{3} \mathrm{Bi}_{9} \mathrm{~S}_{18}-\mathrm{Ag}_{3} \mathrm{~Pb}_{6} \mathrm{Bi}_{7} \mathrm{~S}_{18}\right)$ (Makovicky \& Karup-Møller 1977).

\section{$B i$ - and Ag-bearing galena}

This phase commonly occurs as oriented blebs within felbertalite (Figs. 2a, d) or irregular grains in aikinite and friedrichite (Fig. 2e). Electron-microprobe analyses of three grains show that it contains $\mathrm{Bi}(4.40$ $4.85 \mathrm{wt} \%), \mathrm{Ag}(1.29-1.59 \%)$ and $\mathrm{Cu}(0.1-0.6 \%)$ (Table 3), evidence of the coupled substitution $\operatorname{Ag}(\mathrm{Cu})$ $+\mathrm{Bi}=2 \mathrm{~Pb}$. Minerals of similar compositions, with the $\mathrm{Bi}$ and $\mathrm{Ag}$ contents up to 8.4 and $3.75 \mathrm{wt} \%$, have been reported from several other localities and were referred to as galena-matildite solid-solution (e.g., Cook 1997, Foord \& Shawe 1989).

\section{Wittichenite}

Wittichenite occurs as thin bands, 8 to $20 \mu \mathrm{m}$ wide, surrounding other $\mathrm{Cu}-\mathrm{Ag}-\mathrm{Pb}-\mathrm{Bi}-\mathrm{S}(\mathrm{Se}, \mathrm{Te})$ minerals (Fig. 3a). Two compositional variations of wittichenite are distinguished in the BSE image (Fig. 3a), one richer in $\mathrm{Ag}(3.10 \mathrm{wt} \%)$ and the other poorer in $\mathrm{Ag}(1.59 \mathrm{wt} \%)$, Minor $\mathrm{Pb}(1.21-2.01 \mathrm{wt} \%)$ also is present. Synthetic wittichenite is known to show solid solution from $\mathrm{Cu}_{3} \mathrm{BiS}_{3}$ to $\mathrm{Cu}_{2.5} \mathrm{Ag}_{0.5} \mathrm{BiS}_{3}$ without appreciable substitutions involving $\mathrm{Bi}$ and $\mathrm{Pb}$ (Chang et al. 1988).

\section{Tetradymite}

Tetradymite occurs as subhedral grains 10 to $50 \mu \mathrm{m}$ in size, associated with felbertalite and the bismuthiniteaikinite series (Figs. 3b, d). It contains Se (2.49 wt\%), but is notably free of $\mathrm{Pb}$.

\section{Concluding Remarks}

Electron-microprobe analysis and single-crystal Xray diffraction have confirmed the presence of felbertalite in the Funiushan copper skarn deposit, which in fact is the second locality for this species. Its compositional data show a wide range of coupled substitution according to $\mathrm{Bi}+\mathrm{Ag}=2 \mathrm{~Pb}$ in the (111) $)_{\mathrm{PbS}}$ layers of the crystal structure (Topa et al. 2000), yielding a general formula of felbertalite, $\mathrm{Cu}_{2} \mathrm{Ag}_{\mathrm{x}} \mathrm{Pb}_{6-2 x} \mathrm{Bi}_{8+x}(\mathrm{~S}, \mathrm{Se})_{19}$, with $x$ ranging from 0.64 to 1.33 . In comparison, the low contents of silver in exsolution lamellae of junoite within the felbertalite host may indicate a restricted substitution according to $\mathrm{Bi}+\mathrm{Ag}=2 \mathrm{~Pb}$ in the $(111)_{\mathrm{PbS}}$ layers of single octahedra in the structure of junoite.

In the intergrowths of bismuth sulfosalts in the Funiushan deposit, two groups of minerals may be classified according to their $\mathrm{Ag}$ and Te contents. One is the bismuthinite-aikinite series, mostly free of $\mathrm{Ag}$ and $\mathrm{Te}$ and compositionally intermediate between the ideal compositions of the individual minerals already defined in this series. The other, containing variable contents of $\mathrm{Ag}$ and $\mathrm{Te}$, includes felbertalite, junoite, benjaminite?, schirmerite?, berryite, galena and wittichenite. Se is preferably partitioned in the Ag-bearing phases.

As shown in the experiments on the system $\mathrm{Cu}_{2} \mathrm{~S}$ $\mathrm{PbS}-\mathrm{Bi}_{2} \mathrm{~S}_{3}$ (e.g., Chang et al. 1988), the bismuthiniteaikinite series forms a complete solid-solution above $300^{\circ} \mathrm{C}$ but exsolves into several individual phases. This fact may be applied in interpreting the temperature of formation of the bismuth sulfosalts in the Funiushan deposit. The complex intergrowth and commonly seen exsolution textures among the bismuth sulfosalts tend to indicate that the initial solid phases were formed at temperatures above $300^{\circ} \mathrm{C}$ and experienced exsolution at lower temperatures. The compositional zoning in a 
single grain, from $\mathrm{Cu}_{0.58} \mathrm{~Pb}_{0.58} \mathrm{Bi}_{3.42} \mathrm{~S}_{6}$ (gladite?), through $\mathrm{Cu}_{0.73} \mathrm{~Pb}_{0.73} \mathrm{Bi}_{3.27} \mathrm{~S}_{6}, \mathrm{Cu}_{1.07} \mathrm{~Pb}_{1.07} \mathrm{Bi}_{2.93} \mathrm{~S}_{6}$ (lindströmite?) and $\mathrm{Cu}_{1.53} \mathrm{~Pb}_{1.53} \mathrm{Bi}_{2.47} \mathrm{~S}_{6}$ (friedrichite), to $\mathrm{Cu}_{1.80} \mathrm{~Pb}_{1.80} \mathrm{Bi}_{2.20} \mathrm{~S}_{6}$ (aikinite), may be attributed to the progressive exsolution as temperature decreased below $300^{\circ} \mathrm{C}$.

\section{ACKNOWLEDGEMENTS}

The authors thank Prof. E. Makovicky for information on felbertalite and helpful comments on the chemical compositions of the Funiushan samples. Thanks are also given to Dr. A. Yoshiasa of Osaka University for the access to four-circle X-ray diffractometer. Drs. S. Şavniąr, Associate Editor V. Bermanec, R.F. Martin and an anonymous referee are gratefully acknowledged for their help in improving the manuscript.

\section{REFERENCES}

Borodaev, Yu.S.\& Mozgova, N.N. (1971): New group of the sulfbismuthides of $\mathrm{Ag}, \mathrm{Pb}$ and $\mathrm{Cu}$. In Proc. IMA-IAGOD Meet. 1970, Joint Symposium Volume. Soc. Mining Geol. Japan, Spec. Issue 2, 35-41.

Chang, L.L.Y., Wu, DaQING \& KNowles, C.R. (1988): Phase relations in the system $\mathrm{Ag}_{2} \mathrm{~S}-\mathrm{Cu}_{2} \mathrm{~S}-\mathrm{PbS}-\mathrm{Bi}_{2} \mathrm{~S}_{3}$. Econ. Geol. 83, 405-418.

Ciobanu, C.L. \& CooK, N.J. (2000): Intergrowths of bismuth sulphosalts from the Ocna de Fier Fe-skarn deposit, Banat, southwest Romania. Eur. J. Mineral. 12, 899-917.

CooK, N.J. (1997): Bismuth and bismuth-antimony sulphosalts from Neogene vein mineralisation, Baia Borşa area, Maramureş, Romania. Mineral. Mag. 61, 387-409.

Foord, E.E. \& Shawe, D.R. (1989): The Pb-Bi-Ag-Cu-(Hg) chemistry of galena and some associated sulfosalts: a review and some new data from Colorado, California and Pennsylvania. Can. Mineral. 27, 363-382.

GrICE, J.D. \& FERRARIS, G. (2000): New minerals approved in 1999 by the Commission on New Minerals and Mineral Names, International Mineralogical Association. Can. Mineral. 38, 245-250.

HARRIS, D.C. \& CHEN, T.T. (1976): Crystal chemistry and re-examination of nomenclature of sulfosalts in the aikinite-bismuthinite series. Can. Mineral. 14, 194-205.

Hong Hui-di, Wang Xiang-wen, Shi Ni-cheng \& Peng ZhiZHONG (1982): Xilingolite, a new sulphide of lead and bismuth. Acta Petrol. Mineral. Anal. 1, 14-18 (in Chinese).

Kohatsu, I. \& Wuensch, B.J. (1976): The crystal structure of gladite, $\mathrm{PbCuBi}_{5} \mathrm{~S}_{9}$, a superstructure intermediate in the series $\mathrm{Bi}_{2} \mathrm{~S}_{3}-\mathrm{PbCuBiS}_{3}$ (bismuthinite - aikinite). Acta Crystallogr. B32, 2401-2409.
LARGE, R.R. \& Mumme, W.G. (1975): Junoite, "wittite”, and related seleniferous bismuth sulfosalts from Juno mine, Northern Territory, Australia. Econ. Geol. 70, 369-383.

LiANG GUI-XIANG, GUAN YA-XIAN, LIU WAN \& BiAN TONG-LIN (1981): A new subspecies of bismuth sulfosalt mineral: $\mathrm{PbCuBi}_{7} \mathrm{~S}_{12}$. J. Changchun Inst. Geol. 4, 20-22 (in Chinese).

Lowry, D., Stephens, W.E., Herd, D.A. \& Stanley, C.J. (1994): Bismuth sulphosalts within quartz veining hosted by the Loch Shin monzogranite, Scotland. Mineral. Mag. 58, 39-47.

Makovicky, E. \& Karup-Møller, S. (1977): Chemistry and crystallography of the lillianite homologous series. II. Definition of new minerals: eskimoite, vikingite, ourayite and treasurite. Redefinition of schirmerite and new data on the lillianite-gustavite solid-solution series. Neues Jahrb. Mineral., Abh. 131, 56-82.

\& Makovicky, M. (1978): Representation of compositions in the bismuthinite-aikinite series. Can. Mineral. 16, 405-409.

Marcoux, E., MoëLo, Y. \& Leistel, J.M. (1996): Bismuth and cobalt minerals as indicators of stringer zones to massive sulfide deposits, Iberian pyrite belt. Mineral. Deposita 31, 1-26.

MARIOLACOS, K. (1979): Phase relations in the system $\mathrm{Bi}_{2} \mathrm{~S}_{3}-$ $\mathrm{PbS}-\mathrm{CuPbBiS}{ }_{3}$ at $450^{\circ} \mathrm{C}$. Extension into the system $\mathrm{Bi}_{2} \mathrm{~S}_{3}-$ PbS- $\mathrm{Cu}_{2} \mathrm{~S}$. Neues Jahrb. Mineral., Monatsh., 73-80.

MoËlo, Y., Roger, G., Maurel-Palacin, D., Marcoux, E. \& Laroussi, A. (1995): Chemistry of some $\mathrm{Pb}-(\mathrm{Cu}, \mathrm{Fe})-$ $(\mathrm{Sb}, \mathrm{Bi})$ sulfosalts from France and Portugal: implications for the crystal chemistry of lead sulfosalts in the $\mathrm{Cu}$-poor part of the $\mathrm{Pb}_{2} \mathrm{~S}_{2}-\mathrm{Cu}_{2} \mathrm{~S}-\mathrm{Sb}_{2} \mathrm{~S}_{3}-\mathrm{Bi}_{2} \mathrm{~S}_{3}$ system. Mineral. Petrol. 53, 229-250.

Mozgova, N.N., Nenasheva, S.N., Chistyakova, N.I., Mogilevkin, S.B. \& SivTsov, A.V. (1990): Compositional fields of minerals in the bismuthinite-aikinite series. Neues Jahrb. Mineral., Monatsh., 35-45.

Mumme, W.G. (1980): The crystal structure of nordströmite $\mathrm{CuPb}_{3} \mathrm{Bi}_{7}(\mathrm{~S}, \mathrm{Se})_{14}$, from Falun, Sweden: a member of the junoite homologous series. Can. Mineral. 18, 343-352.

\& WatTs, J.A. (1976): Pekoite, $\mathrm{CuPbBi}_{11} \mathrm{~S}_{18}$, a new member of the bismuthinite-aikinite mineral series: its crystal structure and relationship with naturally- and synthetically-formed members. Can. Mineral. 14, 322-333.

NufFIELD, E.W. \& HARRIS, D.C. (1966): Studies of mineral sulphosalts. XX. Berryite, a new species. Can. Mineral. 8, 407-413.

PRING, A. (1989): Structural disorder in aikinite and krupkaite. Am. Mineral. 74, 250-255. 
(1995): Annealing of synthetic hammarite, $\mathrm{Cu}_{2} \mathrm{~Pb}_{2}$ $\mathrm{Bi}_{4} \mathrm{~S}_{9}$, and the nature of cation-ordering processes in the bismuthinite-aikinite series. Am. Mineral. 80, 1166-1173.

\& Hyde, B.G. (1987): Structural disorder in lindströmite: a bismuthinite-aikinite derivative. Can. Mineral. 25, 393-399.

Pringle, G.J. \& ThorPe, R.I. (1980): Bohdanowiczite, junoite, laitakarite from the Kidd Creek mine, Timmins, Ontario. Can. Mineral. 18, 353-360.

REN YIN-CHENG (1965): Bismuth minerals in a W-Bi quartz vein type deposit in South China. Scientia Geol. Sinica 2, 172-181 (in Chinese).

(1998): Restudy of bismuth sulfosalt minerals in Pangushan wolframite quartz vein deposit, Jiangxi, China. Contrib. to Geology and Mineral Resources Res. 13(4), 117 (in Chinese).

Song Rui-XIAng (1998): 1996 Annual Book of Mineral Resources in China. Geological Publishing House, Beijing, People's Republic of China (in Chinese).

Sugaki, A., Kitakaze, A. \& Shima, H. (1986): Synthesis of cosalite and its relations in the $\mathrm{Cu}-\mathrm{Pb}-\mathrm{Bi}-\mathrm{S}$ quaternary system. In Crystal Chemistry of Minerals (S.J. Mincheva, ed.). Papers and Proc. Gen. Meet., Int. Mineral. Assoc., 13, 291-298.
Topa, D., Makovicky, E., Balić-Žunić, T. \& Berlepsch, P. (2000): The crystal structure of $\mathrm{Cu}_{2} \mathrm{~Pb}_{6} \mathrm{Bi}_{8} \mathrm{~S}_{19}$. Eur. J. Mineral. 12, 825-833.

Criddle, A.J., PAar, W.H. \& BalićŽunić, T. (2001): Felbertalite, $\mathrm{Cu}_{2} \mathrm{~Pb}_{6} \mathrm{Bi}_{8} \mathrm{~S}_{19}$, a new mineral species from Felbertal, Salzburg Province, Austria. Eur. J. Mineral. 13, 961-972.

Ye SHUI-QUAN (1999): Rb-Sr isochron age of Funiushan granite, Jiangsu, China. Jiangsu Geology 23, 148-150 (in Chinese).

ŽÁK, L. (1980): Isomorphism and polymorphism in the bismuthinite-aikinite group. Neues Jahrb. Mineral., Monatsh., 440-448.

MuMME, W.G. \& PAAR, W.H. (1994): Makovickyite, $\mathrm{Ag}_{1.5} \mathrm{Bi}_{5.5} \mathrm{~S}_{9}$, from Baita Bihorului, Romania: the 4P natural mineral member of the pavonite series. Neues Jahrb. Mineral., Abh. 168, 147-169.

ZHANG JIAN (1998): Rare earth element geochemistry of vein skarn in Funiushan copper deposit. Jiangsu Geology 22, 15-18 (in Chinese).

Received March 5, 2001, revised manuscript accepted September 22, 2001. 